\title{
Minor parties, ER policy and the 2020 election
}

\author{
JULIENNE MOLINEAUX* and PETER SKILLING ${ }^{* *}$
}

\begin{abstract}
Since New Zealand adopted the Mixed Member Proportional (MMP) representation electoral system in 1996, neither of the major parties has been able to form a government without the support of one or more minor parties. Understanding the ways in which Employment Relations (ER) policy might develop after the election, thus, requires an exploration of the role of the minor parties likely to return to parliament. In this article, we offer a summary of the policy positions and priorities of the three minor parties currently in parliament (the ACT, Green and New Zealand First parties) as well as those of the Māori Party. We place this summary within a discussion of the current volatile political environment to speculate on the degree of power that these parties might have in possible governing arrangements and, therefore, on possible changes to ER regulation in the next parliamentary term.
\end{abstract}

Keywords: Elections, policy, minor parties, employment relations, New Zealand politics

\section{Introduction}

General elections in New Zealand have been held under the Mixed Member Proportional (MMP) system since 1996. Under this system, parties' share of seats in parliament broadly reflects the proportion of votes that they received, with the caveat that parties need to receive at least five per cent of the party vote or win an electorate seat in order to enter parliament. The change to the MMP system grew out of increasing public dissatisfaction with certain aspects of the previous First Past the Post (FPP) or 'winner-take-all' system (NZ History, 2014). Under this system, seats in parliament were allocated to the candidate (and their party) who received the most votes in the various electorates. The result was what Brian Easton (2012) calls an 'elected dictatorship' where a single party (who were not necessarily the most popular party amongst the nation overall) was able to make decisions unopposed for the duration of the parliamentary term. Since the first MMP election in 1996, neither National nor Labour have been able to secure the 61 seats (in a 120-seat parliament) necessary to govern alone. Consequently - and in line with the original expectations of MMP in New Zealand - policy making during each electoral term has required negotiation and compromise between multiple parties.

One side-effect of the move to proportional representation (PR) has been that elections in New Zealand are quite often close and unpredictable. Even elections where one of the major parties has been polling significantly ahead of the other can end up being decided by the fortunes and decisions of one or more minor party. In 2017, for example, National was polling ahead of Labour during the campaign, and secured 56 seats (out of 120) in the election itself, compared to Labour's 46. National, however, lacked sufficient support from potential coalition partners. The centre-right bloc (National + ACT) secured only 57 seats (Electoral Commission, 2017). This result placed them ahead of the 54 seats secured by the centre-left bloc (Labour + the Greens) but short of a majority. As is well known, the eventual result of the election was decided several weeks after election night when a government was formed consisting of a coalition between Labour and New Zealand First with supply-and-confidence support

\footnotetext{
* Faculty of Culture and Society, AUT, Auckland

${ }^{* *}$ Faculty of Business, Economics and Law, AUT, Auckland
} 
from the Green Party. New Zealand First decided the make-up of the government, as they were also in a position to form one with National.

As has happened in earlier election years, a series of polls released in May and June of 2020 raised the possibility of a single party securing an outright majority at this year's election. Labour surged in these polls to 57 per cent, 59 per cent and 57 per cent, compared to National's results of 31 per cent, 29 per cent and 27 per cent (O’Brien, 2020; One News, 2020; Roy Morgan, 2020)..

Labour's remarkable popularity three months out from the date of this year's election day (October 17) must, however, be seen as the product of unprecedented times. The Covid-19 pandemic placed the country on something similar to a war-time footing, where the public was asked to come together in the face of a clearly defined threat. The Reid Research poll in May 2020 (O'Brien, 2020; Lynch, 2020a) showed 92 per cent approval of the government's handling of the crisis, and very limited support for Simon Bridges (at that point the leader of the National Party) who had struggled to discern when to support and when to challenge the government's response. Support for Bridges as Prime Minister fell to below five per cent, an amazing figure for the leader of the largest party in parliament. The lack of support for Bridges and National in these polls led directly to Bay of Plenty MP, Todd Muller, replacing Bridges as leader. Muller subsequently resigned 53 days later, with Judith Collins being selected as leader on July 14. Collins has debuted with higher public support than her immediate predecessors, but the gap between her and Ardern continues to be large (Colmar Brunton, 2020).

Given the very specific nature of the time period where the polls were conducted, it seems very possible that Labour's support will erode somewhat by the time of the election, and consequently likely that Labour will - in keeping with historical precedent - require support from another party in order to form the next government. Even if Labour retains a comfortable lead over National, the history of MMP reflects New Zealanders' aversion to granting sole power to one party. A poll in July 2020 revealed more of those surveyed wanted a coalition government than those wanting single-party government (Lynch, 2020b). If Labour is perceived to be on track to 'win' the election, left-leaning voters may well decide to vote for the Green Party to ensure that it reaches the five per cent threshold and returns to parliament, and to move any resulting government as far as possible to the left. Indeed, as the National-led coalition governments of 2008-2016 demonstrated, there are short- and long-term advantages in operating a 'surplus majority' coalition that includes more parties than are necessary to achieve a majority (Molineaux \& Skilling, 2014).

While attempts to understand how ER policy might proceed or change after the 2020 election tend to focus (quite naturally) on the stated policy positions of the two major parties, this paper starts from the assumption that the next government will include more than one party. As such, it argues for the importance of understanding the ER policy positions of the minor parties and the priority that each party gives to ER within its broader platform. The question of priorities is important. Even if a minor party holds the balance of power within a parliament and comes to be described as a 'kingmaker', there are limits on the amount of power that it can actually wield. Voters are wary of minor parties that appear to be the tail 'wagging the dog' and are likely to punish parties perceived as overly obstructive. Minor parties - by definition - also possess limited resources and personnel. As a result, they are unable to develop detailed policy across all policy fields. Minor parties within a government must, therefore, make strategic decisions about where they can most usefully exert what influence they do have. In this paper, we understand the influence of minor parties on ER policy after the 2020 election as a function of their policy positions (what do they want?), their policy priorities (how important is ER to them?) and the amount of political power they possess. 


\section{Political Context}

As suggested above, the 2020 election will be contested in a highly specific context. Most obviously, the election campaign will be set against the backdrop of the continuing health and economic fall-out of the Covid-19 pandemic. Early evidence suggested that the crisis led to a worldwide increase in support for incumbent parties (Blais et al., 2020). This may be especially so in New Zealand, where the public has overwhelmingly endorsed the government's handling of the immediate crisis. It is yet to be seen how long this increased support will last, with minor outbreaks continuing, and as the effects of the pandemic on economic activity and employment continue to be felt. Notably, the wage subsidy that has helped sustain 1.7 million jobs is due to end just weeks before the election, with expected job losses and business failures (Bhatia, 2020). The possibility of a major outbreak of cases in New Zealand before election day, or the mishandling of an outbreak, could also make a huge difference to voter sentiment (Smellie, 2020). Since it is largely Labour Ministers, and especially Jacinda Ardern as Prime Minister, that have become the public face of the government's response, the minor parties within the current government will need to think carefully about how they can gain exposure and support before the election.

More broadly, the election can also be taken as a chance for the public to give their verdict on the first term of the sixth Labour government. When the government was formed in 2017, many predicted that the differences between the three parties dictated that this would be fractious and perhaps a short-lived administration. Former ACT leader Richard Prebble (2017) put this sentiment most starkly, claiming that "Jacinda Ardern and the Greens will come to regret forming this coalition of the losers". Judged against these low expectations, the government has been relatively harmonious. At the same time, there have been constant reminders of the differences in political orientation between the parties, and especially of the differences between New Zealand First and the other two parties. In multiple areas, including taxation policy (the debate over a potential Capital Gains Tax), Māori land claims (the land dispute at Ihumātao), light rail for Auckland and (as we shall see) ER policy, New Zealand First has been able to veto or gain concessions on policy proposals put forward by Labour or the Greens. This pattern appears to be intensifying as the election comes close and New Zealand First feels more acutely the need to re-assert its own separate identity.

While Labour enters the campaign period with high levels of support, some left-leaning voters and commentators have complained that this support has come as a result of an unwillingness to expend political capital implementing - or even arguing for - left-wing policies seen as potentially controversial. For Finance Minister, Grant Robertson, this cautious approach was not a bug but a feature of the Labour-led government. He told Sam Sachdeva (2019) that as:

a child of the 1980s, I will never accept that if you're going to make big economic shifts, you should click your fingers and do it [since]... I saw the damage done [in the 1980s] when you switch economic direction without a plan and a process to bring communities with you.

The critique of Labour's cautious approach and Robertson's justification is reminiscent of Bill English's "radical incrementalism" (as discussed in Skilling \& Molineaux, 2017, p. 112) that according to English (2015) - sought to build "popular support for our changes so they will stick". 


\section{Minor Party Landscape}

Voters in the 2017 election gave National 56 seats, Labour 46 seats, New Zealand First nine seats, the Green Party eight seats and ACT one seat. One National MP (Jamie-Lee Ross) subsequently left the Party, remaining in parliament as an independent MP; he has formed a new party and is only contesting the party vote. These initial results generated the highest proportion of seats for the two major parties (102 seats out of 120) ever seen under MMP. Support for major parties tends to rise in elections that voters perceive to be close. (The previous highest proportion of seats for the two major parties came in the last election prior to 2017 that resulted in a change of government: 101 out of 122 seats in 2008.) Related to this point, the parliament that resulted from the 2017 election contained only five parties. This is the fewest since MMP was first used in 1996, and a decrease from the high of eight parties as recently as the 2011-2014 parliament (though three of those parties only held one seat). 2017 saw the disappearance from parliament of United Future and the Māori Party, and disappointing results for parties trying to enter parliament for the first time, such as the Conservative Party and The Opportunities Party (Skilling \& Molineaux, 2017).

Minor parties within parliament also fared worse in 2017. New Zealand First declined from 11 seats in the previous parliament to nine and, more dramatically, the Green Party declined from 14 to eight seats. The Greens' eventual election result of 6.3 per cent was roughly a halving of the 13 per cent support they received in mid-year opinion polls. This marked decrease was the result of controversy over co-leader Metiria Turei's acknowledgment of historic benefit fraud and the resurgence of Labour under Jacinda Ardern's leadership. Indeed, most of the voters who deserted the Greens in 2017 shifted their support to Labour (Shaw, 2018, esp. p. 53). At a practical level, the Greens' and New Zealand First's reduced presence in parliament resulted in fewer resources with which to develop comprehensive policy across a range of areas, and a decreased presence on select committees and in parliamentary debates. Meanwhile, ACT received 0.5 per cent of the national vote and returned to parliament as a one-seat party reliant on an electoral understanding with National. In the three MayJune polls discussed above, support for the Greens averaged between five and six per cent, and support for New Zealand First around three per cent. Both of these parties will be attempting to differentiate themselves from Labour as the election comes closer. On the other hand, ACT appears to be benefiting from National's relative weakness and from leader David Seymour's visibility within the campaign for the End of Life Choice Bill, polling as high as 7 per cent in September (Colmar Bruton, 2020). Even if Seymour fails to retain the Epsom electorate, ACT may return to parliament, and with more MPs.

National's openness to forming a post-election coalition deal with New Zealand First has shifted across the year, as both parties' fortunes have stayed low, and as National changed leaders in response to its own poor polling. Under leader Simon Bridges (February 2018 - May 2020), National ruled out any sort of relationship with New Zealand First. This approach was interpreted as a strategic attempt to push New Zealand First below five per cent and out of parliament, thus depriving Labour of that party's continued support. That strategy made some sense when support for Labour and National was relatively close. It makes less short-term sense in a setting where Labour is well ahead of National, leaving National needing all of the potential support it can get. National's stance appeared to soften under the (very brief) leadership of Bridges' successor, Todd Muller (Moir, 2020a). On assuming the leadership in July, Judith Collins "appear[ed] to have ruled out working with NZ First after the election" (Jones, 2020), although her phrasing left some space for negotiation if a deal with New Zealand First made sense after election night. Specifically, Collins said that forming a government with New Zealand First was "not likely, because I don't know if his party's going to be there after the election" and that the signal that the two parties could not work together was not necessarily a strongly- 
held personal commitment but rather that "the caucus has decided it" (cited in Jones, 2020). With growing support for potential partner the ACT Party, Collins later appeared to relish the thought of New Zealand First being electorally "destroyed" (Young, 2020b).

There are a number of micro-parties contesting the election, with little hope of being elected. These include the Sustainable New Zealand Party (a blue-green party), several parties running on a platform of social conservatism (Vision New Zealand, New Conservatives, One Party), and The Opportunities Party (TOP). We do not include them in our survey. We also do not cover the Advance NZ Party headed by sitting MP Jami-Lee Ross who began the term as a National Party MP. Ross' Advance NZ announced in July their merger with the New Zealand Public Party (NZPP), which was not registered with the Electoral Commission in time to appear on ballots for the party vote. An odd bedfellow for Ross, the NZPP believes a range of conspiracy theories, including that "mandatory vaccination [is] a violation of human rights" and its leader suggested that "Covid-19 was a bioweapon designed to be used on civilians around the world" (Walls, 2020).

\section{ER Policy since 2017}

The smaller number of parties in the 2017-2020 parliament and their division into three governing parties and two opposition parties makes for a relatively simple summary of the minor parties' positions on ER policy proposals since 2017. ER proposals introduced by the government in this term have been able to rely on the support of Labour and the Greens (although the Greens have typically argued for stronger protections and regulations) and on the opposition of National and ACT. In many instances, New Zealand First have eventually supported the proposals but made their support conditional on specified amendments.

Table 1: Minor Parties' Positions on ER legislation 2017-2020

\begin{tabular}{|l|l|l|l|l|}
\hline & $\begin{array}{l}\text { ER policy closest to } \\
\text { which major party* }\end{array}$ & $\begin{array}{l}\text { Number of MPs } \\
\text { Number }\end{array}$ & $\begin{array}{l}\text { ERA } \\
\text { Amendment } \\
\text { Act 2018 }\end{array}$ & $\begin{array}{l}\text { Fair Pay Agreement } \\
\text { consultation }\end{array}$ \\
\hline $\begin{array}{l}\text { ACT } \\
\text { Party }\end{array}$ & National & 1 & Oppose & Oppose \\
\hline $\begin{array}{l}\text { Green } \\
\text { Party }\end{array}$ & Labour & 8 & Support & Support \\
\hline $\begin{array}{l}\text { Māori } \\
\text { Party** }\end{array}$ & Labour & - & Support & Unclear \\
\hline $\begin{array}{l}\text { New } \\
\text { Zealand } \\
\text { First }\end{array}$ & Labour & 9 & Support* & Unclear \\
\hline
\end{tabular}

* See also additional comments and caveats in the text.

** The Māori Party did not exist in parliament at the time of these bills. Its position is presumed on the basis its previous voting record and public statements.

The Employment Relations Amendment Act (ERAA) (2018) contained 16 main provisions that, in large part, reversed the changes to ER regulation that had been passed by the preceding National-led administration (Employment New Zealand, 2018). According to Workplace Relations and Safety Minister, Iain Lees-Galloway, (in New Zealand Parliament, 2018) the Act's provisions fell into three main categories: the strengthening of workers' rights, the encouragement of collective bargaining, and 
the strengthening of union rights. The Act was passed in the face of opposition from National and ACT. While Labour and the Greens supported the legislation in its entirety, some provisions of the Bill were amended as the price of New Zealand First's support. As noted in Skilling (2019, p. 65), it was New Zealand First who "argued for retaining 90-day trials for workplaces with less than 20 employees, for allowing some businesses to not opt in to multi-employer collective agreements (MECA), and for placing some restrictions on union access to workplaces" (see also Mitchell, 2018).

Labour's manifesto at the 2017 election included a commitment to "[i]ntroduce Fair Pay Agreements [FPAs] that set fair, basic employment conditions across an industry". As the parliamentary term proceeded, the government convened the Fair Pay Agreements Working Group that delivered its report in December 2018. On receiving the report, the government undertook further policy work and, in October 2019, released a Discussion Paper that invited submissions from interested parties. National claimed that this timeline indicated that the government would not follow through in this term on Labour's promise to introduce FPAs. Todd McClay, National's Workplace Relations Spokesman, offered his opinion that "the Government's clearly quite rattled by the concerns of the business community' and that 'putting it out to consultation after a very, very expensive and extensive working group is just them kicking it for touch" (Rutherford, 2019).

In terms of the minor parties, ACT was a strident critic of the FPAs, claiming that they would "harm our economy and the opportunities it creates". More generally, ACT argued that "centralised bargaining will make it harder for firms to remain competitive", harming not just those firms but also, according to ACT, workers who will be laid off as a result. The Green Party was an enthusiastic supporter of the FPA proposals, describing FPAs as "a crucial tool to provide greater fairness at work for everyone" and arguing that they would "benefit everyone", including employers who "won't be undercut by cowboys who exploit workers to lower their operating costs instead of competing fairly on quality and productivity" (Logie, 2019). The Greens argued "for the strongest possible regime" (Manch, 2020), with Jan Logie arguing that "if we're to really to get to the heart of the problem ... we've got to take a strong legislative response" (cited in Manch, 2020). New Zealand First did not articulate a clear position on FPAs, though Winston Peters seemed less than enthusiastic, noting that change to the ER system necessarily takes time. Asked whether New Zealand First was acting as a handbrake on ER reform, Jacinda Ardern replied that "consensus does take time" and that "both New Zealand First and the Greens have maintained strong voices" (cited in Tibshraeny, 2019).

Other ER initiatives since the 2017 election have included the extension of the Support Workers Pay Equity law to cover mental health and addiction support workers who were specifically excluded under the Care and Support Workers (Pay Equity) Settlement Act 2017. New Zealand First and the Greens supported this extension. The Labour-New Zealand First coalition agreement contained a pledge to gradually raise the minimum wage to $\$ 20$ per hour, by 2020 . This has happened, although it will not reach $\$ 20$ until April 2021. There has been a rise in base benefit levels, although the government has been reluctant to implement larger benefit increases as advocated by the Welfare Working Group. The coalition agreement also included commitments to programmes for "long-term unemployed to improve work readiness" and to "take serious action on migrant exploitation, particularly of international students". Since 2017, paid parental leave has been increased from 18 to 26 weeks, supported by all government parties but opposed by ACT. The government has set an expectation for the public sector to close the gender pay gap in its ranks, a policy area fronted by Green Party MP and Minister for Women Julie Anne Genter. This has happened to some extent (Manch, 2019). Progress has also been made on a key New Zealand First policy of re-entering the Pike River Mine, where an explosion in 2010 killed 29 miners. 


\section{The Minor Parties: Policy positions, priorities and power}

\section{ACT Party}

ACT's policy positions stem from a set of beliefs based on the ideological position of classical liberalism. Their core beliefs hold that human beings "are the owners of their own lives and must be free to act according to their own judgments so long as they accept and respect the like freedom of others" and that government laws and actions must be limited to those "necessary to secure freedom of the individual from the actions of others [including the state] which could constrain individuals from exercising ownership of their own lives" (ACT, n.d.). This vision of "expanded personal liberty and responsibility" has obvious implications for the regulation (or deregulation) of ER. In this vision, there is little space for mandated standards, or for encouragement of collective action. For ACT (n.d.), "[e]mployment should be by private contract between employee and employer, and membership of any association of either employees or employers should be entirely voluntary".

The Party remains resolutely opposed, therefore, to any suggestions of centralised bargaining, since it believes that all conditions of employment should be negotiated privately between competitive firms and individual workers. ACT believes, further, that this vision of ER, as based on private contracts between employers and employees, is correct not just in principle but also for pragmatic reasons. Its claim is that maximising the freedoms and flexibility of employers is good for everyone, while increased regulation and requirements for centralised bargaining harm everyone, including the workers that such regulation claims to protect (see ACT, 2019).

ACT's ideological position can be seen most clearly in its position on paid parental leave. Seymour voted against the extension of paid parental leave to 26 weeks, saying, “... the ACT party stands alone in favour of the taxpayer, opposing the continual expansion of our entitlement culture and society in this country" (New Zealand Parliament, 2017). At the same time, ACT has previously stated its support for paid leave for parents who are facing unplanned-for expenses, such as the arrival of a premature baby or multiples. This distinction is based on ACT's belief that individuals should take responsibility for their own choices (including the choice to have children) but that there is a case for state support in situations of unchosen costs.

ACT was generally supportive of the government's Covid-19 response, including the wage subsidy. In keeping with a general opposition to government regulation and a support for lower taxes, leader David Seymour advocated tax relief for businesses, the removal of tax on redundancy payments made to those who lost their jobs during lockdown, and a suspension of any new regulatory measures that might add costs to businesses. Seymour also advocated for pay cuts for higher paid public servants and Members of Parliament, and a delay in the pre-arranged increase in the minimum wage, calling it "illogical to be introducing a minimum wage increase at the exact time that the government is giving money to businesses to pay wages" (New Zealand Parliament, 2020).

With less than one per cent of the party vote in 2017 , and polling below the margin of error for much of this term, ACT appeared to have a precarious future. Their fortunes have improved sufficiently in 2020, though, to suggest that leader David Seymour is likely to make it back into parliament with several colleagues. Seymour achieved a relatively high profile for the leader of a one-MP party currently in opposition. Some of this came through comic turns on the 2019 series of Dancing with the Stars, some came through his involvement with the high-profile End of Life Choice Bill, a Bill that has taken the Party back to its classical social liberal roots. There will be a referendum question on the Bill at the 2020 General Election, providing on-going media coverage for Seymour and the lesser- 
known Deputy Leader Brooke van Velden. The Party has also courted the support of gun owners, upset by changes to gun laws following the 2019 Christchurch terror attack; Seymour was the only MP to vote against the initial legislation. Nicole McKee, a "prominent gun advocate" (Sadler \& Stanford, 2020), has been placed at number three on the party list. With the National Party performing badly and the possibility that New Zealand First may not return to parliament, ACT is a safe 'protest vote' for those opposing the re-election of the Labour-led government.

Policy position: ACT's position on ER matters is straightforward and clear-cut. It has opposed the government's ER proposals during this term and would support National's stated intention to reverse all of these changes as soon as it gets a chance.

Priority: As a one-seat party, ACT cannot emphasise everything. However, the core debates within the field of ER directly invoke ACT's values. As a very minor party, ACT's brand proposition requires it to stay true to its stated principles and values.

Power: A one-seat party since holding five seats in the 2008-2011 parliament. It is currently polling at a level that will likely bring additional members into the next parliament, though this is partly related to perceptions of National's weakness.

\section{The Green Party}

As its name indicates, the Green Party has a strong commitment to environmental issues. At the same time, a standard left-wing concern for social inequities and social justice is deep in the DNA of the party. The Green Party has its origins in the left-wing Values Party that attracted over five per cent in the 1975 election: a result that would have seen it enter parliament under MMP, but that generated no seats under the prevailing FPP system. The Green Party, officially formed in 1990, was subsequently a founding member of the left-wing Alliance Party that entered parliament with 13 MPs in the first MMP election in 1996 (Molineaux \& Skilling, 2014).

In line with these left-wing roots, the Greens hold a vision of society marked by fundamental conflict between the owners of capital (who benefit from the status quo) and those who have to sell their labour to survive. In contrast to ACT's belief in the current existence of a fundamentally fair society in which workers and employers are able to negotiate fairly for their mutual benefit, the Greens insist instead that "the relationship between employee and employer is not equal. An employee can't fire their boss, they can't cut or change their hours, and they can't send their employer into an unsafe situation" (Jan Logie, in New Zealand Parliament, 2018). For the Green Party, the inherently unequal nature of the employment relationship means that the benefits of economic activity are not fairly shared. Rather, even during a period of economic growth and job growth, and

many, many working people are now struggling under working more hours but not getting the financial benefit out of it. While productivity has increased, their share of that profit has not been returned to them. It has gone to profit for the businesses, or the owners, or the shareholders, and not the people doing the work (Logie, in New Zealand Parliament, 2018).

The Green's Supply and Confidence Agreement with the Labour-led government included a commitment to "[e]liminate the gender pay gap within the core public sector with substantial progress within this Parliamentary term, and work to ensure the wider public sector and private sector is on a similar pathway". Young (2020) reports that this commitment was kept, with the gender pay gap in the public service falling "from 12.2 per cent in 2018 to 10.5 per cent in 2019". As Minister for Women, Green MP, Julie Anne Genter was closely involved in initiatives to achieve pay parity in the public 
sector and in the unanimous passing into law of the Equal Pay Amendment Bill, under which "New Zealanders working in female-dominated professions will have a clearer pathway for pay equity" (Little \& Genter, 2020). The Greens also supported a strong legislative response to the Fair Pay Agreement proposals, supporting the Council of Trade Union's calls for

reasonable thresholds for initiating FPA negotiations, proper representation for workers through their unions, [the covering of] contractors as well as employers, and [the stipulation that] when a majority of workers and majority of employers have settled an agreement, that should be the final word on the matter (Logie, 2019).

While happy with their decision to remain outside of formal coalition in the 2017-2020 term, co-leader James Shaw has stated that "the party would consider being in Coalition next time depending on circumstances including who else was there, how big it was and how strong the agree to disagree clauses were" (Young, 2020).

The Party's strong left-wing commitments do not seem to have been well understood by some political commentators and pundits, who sometimes suggest that the Greens could maximise their political leverage by remaining open to the possibility of forming a 'blue-green' coalition with National. Some commentators posit "a growing space for politicians who want to save the world without necessarily overhauling the entire economic system" (The Press, 2019). For their part, the Green Party sees environmental issues as intrinsically tied to economic policy. Co-leader James Shaw noted that "National would need to "change everything about the way that they're doing business" if it were to ever work with the Green Party" and went on to claim that National was "speaking out of both sides of their mouth on climate change" (One News, 2019).

The Greens lost significant vote share in the lead-up to the 2017 election with key events being the resignation of co-leader Metiria Turei and Jacinda Ardern becoming Labour Party leader. Co-leader James Shaw says the Party lost significant "soft" left voters to Labour following Ardern's elevation to that Party's leadership (Shaw, 2018, p. 53). The Greens' polling has continued to be low during this term of government, dropping close to or even below the five per cent threshold in some surveys. While high-profile MP, Chlöe Swarbrick, is campaigning hard for the Auckland Central seat currently held by the retiring National MP, Nikki Kaye, Labour has not signalled for its voters to vote for Swarbrick, and the Greens need to clear the five per cent threshold to be confident of returning to parliament (Cooke, 2020). If polls closer to the election suggest that the Greens may not make it back into parliament, some Labour voters may consider supporting the Party to prevent its votes being wasted. Assuming that the Greens are returned to parliament, their place in a Labour-led government is uncertain. National governments under John Key practiced a 'surplus-majority' strategy of partnering with more support parties than necessary (Boston, 2011) and we do not know yet whether Labour will follow this example. Labour may see short- and long-term strategic advantage in including the Greens in a governing arrangement even if they do not need their votes to secure a majority in parliament. Doing so would (1) retain Green MPs who have performed well in ministerial roles, (2) offer a stronger mandate for progressive policies and (3) maintain good relationships for future elections when the Greens' support is required. If Labour is open to working with the Greens, any deal (whether a formal coalition, or a confidence and supply agreement) will need ratification from the broader Green Party membership, who may be concerned about the damage to their brand from the compromises of government.

Policy position: The Green Party's position on ER matters is straightforward and clear-cut (see Green Party, 2020). It has supported the government's ER proposals during this term and has typically argued for stronger protections and regulation in favour of workers and unions. 
Priority: The Green Party has a commitment to social justice and labour rights built into its history and its core commitments. Their capacity to push their views on ER is limited by the relatively low number of MPs that they currently have in parliament. It seems unlikely that they will have markedly more MPs after the 2020 election.

Power: The Greens' power after the election depends on whether Labour requires their support to form a government (and, of course, whether they are returned to parliament). Current polling leaves both questions uncertain, though history suggests that the Greens will return, and that Labour will require some support to form a government.

\section{The Māori Party}

The Māori Party is the only minor party not currently in parliament that we are reviewing. Having been out of office for a term, they lack the resources and profile that comes with parliamentary representation. Regaining a seat in parliament will be an uphill battle. The Party has been in a rebuilding phase since their 2017 loss, with a new president (Che Wilson) and co-leaders (John Tamihere and Debbie Ngarewa-Packer). Their path to re-election comes via the Māori electorate seats, where polling - if done at all - is notoriously difficult, adding to the problem of predicting their electoral chances.

Previously, the Māori Party has had confidence and supply arrangements with the National-led governments of John Key and Bill English (2008-2017), in exchange for ministerial posts and policy wins, such as Whānau Ora. Founded as a breakaway from the Labour Party in 2004 over the Foreshore and Seabed issue, the Māori Party succeeded in wresting the Māori electorates away from Labour, before Labour gradually won them back. Much of the old animosity between the parties has evaporated, particularly as the line-up of politicians from the 2004-era have retired. New co-leader John Tamihere, a former Labour MP, is however an important exception to this. The last two Māori Party presidents have commented that they are open to working with the Labour Party to form a government (Moir \& Patterson, 2020).

There are two key electorate races for the Māori Party: Tāmaki Makaurau and Te Tai Hauāuru. In both cases, there are complex dynamics based on the prominence and connections of candidates, perceptions of Labour's performance on Māori issues over the last three years, and the strategies of competing parties. These issues are well covered by Māori political commentator Morgan Godfery $(2018 ; 2020)$. At the time of writing, there have been no polls to indicate how the contests in the two electorates are shaping up. Labour's willingness to place its Māori electorate MPs on the list in 2020 means voters in those electorates can give their party vote to Labour and their electorate vote to the Māori Party candidate, creating a higher level of Māori representation in parliament (Moir, 2020b). Labour removed its Māori electorate candidates from the list prior to the 2017 election in a bid to win the seats, as voting for Labour candidates was the only way to guarantee their return to parliament. This strategy contributed to its clean sweep of the seats in 2017 (Moir, 2020b).

The Mana Movement (Skilling \& Molineaux, 2017) will not stand candidates in 2020 and has given its support (and mailing lists) to the Māori Party. Mana has not been de-established with the Electoral Commission however, so it could still appear on the ballot as a party vote option (Braae, 2020).

Policy position and Priority: While they do not give ER policies a high priority, the Māori Party consistently voted against National's ER initiatives while in government with them (Molineaux \& 
Skilling, 2014). For 2020, they are wanting a share of the post-Covid-19 recovery budget to go directly to Māori, for Māori to decide how it is spent. They have yet to articulate any ER-specific policies.

Power: As discussed above, it is difficult to assess the Party's chances of returning to parliament this year, given that their chances rely on winning a Māori electorate seat, for which reliable polling has not been done.

\section{New Zealand First}

New Zealand First was the 'kingmaker' following the 2017 General Election: neither National nor Labour had the votes to create a government without their support. Some commentators point to bad feeling between New Zealand First leader Winston Peters and the National Party, after details of a pension over-payment to Peters was made public weeks before the 2017 Election (Soper, 2017). Peters later pursued the issue through the courts, suing nine people, including former National Party government ministers Anne Tolley and Paula Bennett, alleging his privacy had been breached (Soper, 2017). Peters' case was eventually dismissed, and he was ordered to pay almost $\$ 320,000$ in costs, including over $\$ 100,000$ to Tolley and Bennett (Hurley, 2020). Peters, himself, describes the decision to support Labour rather than National as being about the slight leftwards swing in the votes, and a view that his Party could work more constructively with Labour to advance policies they had in common - a change rather than a "slightly modified status quo" (Peters, 2018a, p. 44). Certainly, on the ER front, New Zealand First has had more in common with Labour than National (Skilling \& Molineaux, 2017). Long a party that has promoted regional development and jobs for New Zealanders, Peters talked of the need for capitalism to regain its "human face" and the rejection of the sort of "unbridled, irrational neoliberalism" (Peters, 2018b) that - so he claimed - had been advanced by previous governments including the 2008-2017 National-led one.

A socially conservative party, New Zealand First has been keen to strategically distance itself from the Green Party, and is campaigning on its ability to stifle more radical or left-wing policies supported by its government partners. The list of this blocking influence is considerable (Mclauchlan, 2020) and New Zealand First is hoping to pick up some support from right-leaning voters who would like New Zealand First back in parliament to act as a 'handbrake' on a likely re-elected Labour government.

New Zealand First has always balanced its support for a better deal for workers with the needs of business and industry. Minister for Regional Economic Development Shane Jones describes himself as a "pro-industry politician" (Tibshraeny, 2019). Retiring at the 2020 election, MP Clayton Mitchell's contributions to parliamentary debates on the ERAB (2018) include the statement that New Zealand First is "certainly... very, very pro-business. They are the lifeblood of this country, as too are our workers" (Mitchell, in New Zealand Parliament, 2018). While commending the Bill's enhancement of union rights, Mitchell also noted that he had once belonged to a union but then "realised [that he] had the strength of character and [that he] could go and negotiate" which is a very specific and limited endorsement of the importance of unions (Mitchell, in New Zealand Parliament, 2018). Mitchell seemed to take greatest pride in the exemptions and amendments that New Zealand First had negotiated (including the provision that 90-day trials would remain available for small and medium sized businesses) which tended to be areas where the law eventually did not change.

Speaking to the Council of Trade Unions conference in 2019, Winston Peters dampened unionists' hopes of his party moving quickly to support fair pay agreement legislation. He distanced New Zealand First from both Labour and National, pitching it as a 'centrist party': "This is why we listen to trade unions. This is why we listen to farmers. And this is why we also listen to business leaders", he said (Peters, in Tibshraeny, 2019). Despite his comments following the 2017 election that were damning 
of neoliberalism and pointed to the failures of free markets, Peters indicated New Zealand First was not a force for rapid change, telling conference delegates that

[s]ignificant change to economies and government cannot occur overnight without massive disruption to the most vulnerable - despite Marxists and Neoliberals' parallel claims to the contrary. We are in our first term. If you expect a massive shift in industrial relations in just three years, you are asking for the impossible (Tibshraeny, 2019).

New Zealand First goes into the 2020 election with some wins and is campaigning hard for the provincial vote. It secured a large budget for the Provincial Growth Fund, which it has been left to manage and obtain the credit for - but questions remain over how many jobs it has actually created (Bracewell-Worrall, 2019; Coughlan, 2020).

The Party faces significant problems in its quest to return to parliament. The first of these is their current very low polling. History suggests that the Party will have to work hard to reverse this. The two previous times that New Zealand First have been a formal part of government, (as a coalition partner for National 1996-1998 and as a confidence and supply partner for Labour 2005-2008) have ended badly, and the Party dropped below the five per cent threshold on both occasions at the subsequent election. The Party's struggle to improve their polling this year is complicated by a Serious Fraud Office (SFO) enquiry. In this parliamentary term, there have been journalistic investigations into the Party's ties to figures in the racing and fishing industries (Espiner \& Newton, 2020; Hancock, 2020); and the Electoral Commission asked the police to investigate the role of the New Zealand First Foundation, a fundraising body for the Party whose donations the Party has not declared on its electoral returns. The police forwarded the case to the SFO, which has said it will report back before the election (Espiner, 2020). As Mclauchlan (2019) notes of an earlier (2008) SFO enquiry involving New Zealand First, the scandal "dominated the 2008 election. John Key ruled out working with Winston Peters. Helen Clark didn't. Labour lost, and New Zealand First was voted out of parliament".

Policy position: New Zealand First positions itself as a centrist party seeking to balance the interests of workers and business. In this self-appointed role of restraining the excesses of the centre-left and the centre-right, they opposed the ER agenda of the previous National-led government and have imposed constraints over many of the ER proposals of this current government.

Priority: Apart from their emphasis on regional job creation and its support for raising the minimum wage to $\$ 20$ an hour, ER has not been an area of high priority for the Party.

Power: Current polling suggests that New Zealand First will struggle to fill a kingmaker role after this year's election - or even to return to parliament - meaning that the power they have exercised for the previous three years will likely be curtailed.

\section{Conclusion}

The lead-up to the 2020 election, as was the case in 2017 and 2014, is full of instability and drama as parties rearrange their line-ups, and scandals fill the media headlines. 2020 is unique though, as New Zealand is facing the threat of a return of Covid-19 and the need to address the economic and social upheavals it has caused. Covid-19-related issues have dominated the political and media space for many months, with the Prime Minister very visible. Parties have been slow in releasing policies. The response to Covid-19 has resulted in an upending of parties in the polls, with National falling and the incumbent Labour rising. Among the small parties, New Zealand First is fighting for its life, while 
ACT seems on-track for an increase in elected representatives. While the Green Party has also been close to the five per cent threshold, its fortunes look more secure than New Zealand First. At the time of writing, there have been no public polls in the Māori electorates. On current polling, the 2020 election is likely to result in a return of the Labour Party to government, possibly with the Green Party as allies. National (under new leadership) is fighting to restore its credibility and its popularity with voters. This electoral context, combined with the ongoing uncertainties associated with the health and economic impacts of a pandemic, means that the run up to the election is likely to be volatile.

Labour was elected with some bold ER policy platforms, including The Future of Work programme. While it has reversed much of National's ER reforms from the 2008-2017 period, and has made incremental steps on paid parental leave, raising the minimum wage, and addressing the gender pay gap, Labour has not been willing to force New Zealand First's hand on more radical change. More substantial changes to the ER landscape looks far more likely if the 2020 election delivers a government where Labour is not reliant on forgoing a consensus with New Zealand First as well as with the Greens.

\section{References}

ACT. (n.d.) Our Principles. ACT. https://www.act.org.nz/principles

ACT. (2019, January 30). Fair Pay Agreements: “Labour Won't Work”. ACT https://www.act.org.nz/fair_pay_agreements_labour_won_t_work

Bhatia, R. (2020, July 8). Wage subsidy loss 'major blow' to Auckland, business leader calls for extension. Stuff. https://www.stuff.co.nz/business/300051160/wage-subsidy-loss-major-blowto-auckland-business-leader-calls-for-extension

Blais, A., Bol, D., Giani, M., \& Loewen, P. (2020). COVID-19 lockdowns have increased support for incumbent parties and trust in government. LSE (London School of Economics. https://blogs.lse.ac.uk/politicsandpolicy/covid19-lockdowns-democracy/

Boston, J. (2011). Government formation in New Zealand under MMP: theory and practice. Political Science 63(1): 79-105. doi:10.1177/0032318711406879:

Braae, A. (2020, June 20). Rivalry over: Mana Movement throws its full support behind Māori Party for 2020. The Spinoff. https://thespinoff.co.nz/politics/20-06-2020/rivalry-over-manamovement-throws-its-full-support-behind-maori-party-for-2020/

Bracewell-Worrall, A. (2019, December 7). Revealed: Provincial Growth Fund costing $\$ 484 \mathrm{kper}$ fulltime job. Newshub. https://www.newshub.co.nz/home/politics/2019/12/revealed-provincialgrowth-fund-costing-484k-per-full-time-job.html

Colmar Brunton. (2020, September 22). 1 News Colmar Brunton poll 17-21 September 2020. https://static.colmarbrunton.co.nz/wp-content/uploads/2019/05/PRELIM_17-21-September2020_1-NEWS-Colmar-Brunton-Poll-report-.pdf

Cooke, H. (2020, July 17). Chlöe Swarbrick could save the Green Party in Auckland, but Labour would have to get out of the way. Stuff. 
https://www.stuff.co.nz/national/politics/300060057/chle-swarbrick-could-save-the-greenparty-in-auckland-but-labour-would-have-to-get-out-of-the-way

Coughlan, T. (2020, April 7). Shane Jones concedes Provincial Growth Fund hasn't created enough jobs, promises a fix. Stuff.

https://www.stuff.co.nz/national/health/coronavirus/120883746/shane-jones-concedesprovincial-growth-fund-hasnt-created-enough-jobs-promises-a-fix

Easton, B. (2012). The politics of NZ (Inc). https://www.eastonbh.ac.nz/2012/12/the-politics-of-nzincl

Electoral Commission. (2017). 2017 general election - official result. https://www.electionresults.govt.nz/electionresults_2017/

Employment New Zealand (2018). Employment Relations Amendment Bill 2018. https://www.employment.govt.nz/about/employment-law/employment-relations-amendmentact-2018/

English, B. (2015, June 25). Annual John Howard Lecture to Menzies Research Centre. https://www.beehive.govt.nz/speech/annual-john-howard-lecture-menzies-research-centre

Espiner, G. (2020, April 21). SFO decision over NZ First Foundation will come before election. RNZ (Radio NZ). https://www.rnz.co.nz/news/in-depth/414730/sfo-decision-over-nz-firstfoundation-will-come-before-election

Espiner, G., \& Newton, K. (2020). NZ First Foundation received tens of thousands of dollars from donors in horse racing industry. RNZ (Radio NZ). https://www.rnz.co.nz/news/indepth/409320/nz-first-foundation-received-tens-of-thousands-of-dollars-from-donors-inhorse-racing-industry

Godfery, M. (2018). Did the Māori electorates decide the election? In S. Levine (Ed.), Stardust and substance: The New Zealand general election of 2017 (pp. 390-399). Victoria University Press.

Godfery, M. (2020, January 29). Can Marama Davidson really win Tāmaki Makaurau? Metro.https://www.metromag.co.nz/society/society-politics/can-marama-davidson-reallywin-tmaki-makaurau

Green Party (2020). Workforce Policy. https://www.greens.org.nz/workforce_policy

Hancock, F. (2020, June 10). Why the delay to get cameras on boats? Newsroom. https://www.newsroom.co.nz/2020/06/10/1224189/why-the-delay-to-get-cameras-on-boats

Hurley, S. (2020, July 20). 'Winston Peters to pay $\$ 320,000$ over failed superannuation leak privacy court case'. New Zealand Herald.

https://www.nzherald.co.nz/business/news/article.cfm?c_id=3\&objectid=12348961

Jones, N. (2020, 18 July). Election 2020: National leader Judith Collins rules out working with NZ First, says Winston Peters is on way out. New Zealand Herald. https://www.nzherald.co.nz/nz/news/article.cfm?c id=1\&objectid=12349054 
Little, A. \& Genter, J. A. (2020, July 23). Equal Pay Amendment Bill Passes with Unanimous Support. https://www.beehive.govt.nz/release/equal-pay-amendment-bill-passes-unanimous-support

Logie, J. (2019, October 17). Fair Pay Agreements mean fairness at work - for everyone. Green. https://www.greens.org.nz/fair-pay-agreements-mean-fairness-work--everyone

Lynch, J. (2020a, May 18). Overwhelming number of Kiwis back Government's lockdown decision. Newshub. https://www.newshub.co.nz/home/politics/2020/05/newshub-reid-research-polloverwhelming-number-of-kiwis-back-government-s-lockdown-decision.html

Lynch, J. (2020b, July 26). Newshub-Reid Research poll: Voters want minor parties in government. Newshub. https://www.newshub.co.nz/home/politics/2020/07/newshub-reid-research-pollvoters-want-minor-parties-in-parliament.html

Mclauchlan, D. (2019, November 19). The NZ First donations scandal is very serious, and won't let Jacinda Ardern hide. The Spinoff. https://thespinoff.co.nz/politics/19-11-2019/the-nz-firstdonations-scandal-is-very-serious-and-wont-let-jacinda-ardern-hide/

Mclauchlan, D. (2020, July 2). The Winston Peters paradox. The Spinoff. Available at: https://thespinoff.co.nz/politics/02-07-2020/the-winston-peters-paradox/

Manch, T. (2019, November 28). Gender pay gap in public service drops to 10 per cent. Stuff. https://www.stuff.co.nz/national/politics/117727485/gender-pay-gap-in-public-service-drops$\underline{\text { to-10-per-cent }}$

Manch, T. (2020, February 10). Greens push for most powerful labour law as Government negotiates on Fair Pay Agreements. Stuff. https://www.stuff.co.nz/national/politics/119360655/greenspush-for-most-powerful-labour-law-as-government-negotiates-on-fair-pay-agreements

Mitchell, C. (2018). New Zealand First celebrates passing of employment relations bill. NZ First. https://www.nzfirst.nz

Moir, J. (2020a, May 25). New leader eases tensions between National and NZ First. RNZ (Radio NZ). https://www.rnz.co.nz/news/political/417463/new-leader-eases-tensions-betweennational-and-nz-first

Moir, J. (2020b, June 2). Labour switches up strategy for Māori seats. RNZ (Radio NZ). https://www.rnz.co.nz/news/political/418056/labour-switches-up-strategy-for-maori-seats

Moir, J. \& Patterson, J. (2020, February 7). Māori Party President wary of National partnership: 'It kicked us out'. RNZ (Radio NZ). https://www.rnz.co.nz/news/political/409006/maori-partypresident-wary-of-national-partnership-it-kicked-us-out

Molineaux, J. \& Skilling, P. (2014). The minor parties: Policies, priorities and power. New Zealand Journal of Employment Relations, 39(1), 33-51.

New Zealand History. (2014). The road to MMP. https://nzhistory.govt.nz/politics/fpp-to-mmp 
New Zealand Parliament (2017, November 8). Parental Leave and Employment Protection Amendment Bill - First Reading. https://www.parliament.nz/en/pb/hansarddebates/rhr/combined/HansDeb_20171108_20171108_68

New Zealand Parliament (2018, February 1). Employment Relations Amendment Bill — First Reading. https://www.parliament.nz/en/pb/hansarddebates/rhr/combined/HansDeb_20180201_20180201_20

New Zealand Parliament (2020, March 17). Government Statement and Responses - COVID-19Emergency Economic Package. $\quad$ https://www.parliament.nz/en/pb/hansarddebates/rhr/combined/HansDeb_20200317_20200317_04

O’Brien, T. (2020, 18 May). Jacinda Ardern goes stratospheric, Simon Bridges is annihilated. Newshub. https://www.newshub.co.nz/home/politics/2020/05/newshub-reid-research-polljacinda-ardern-goes-stratospheric-simon-bridges-is-annihilated.html

One News. (2019, July 30). National 'pretty desperate' for coalition partners, Greens co-leader James Shaw says. https://www.tvnz.co.nz/one-news/new-zealand/national-pretty-desperatecoalition-partners-greens-co-leader-james-shaw-says

One News. (2020, 21 May). Pressure mounts as National falls to 29\%, Labour skyrockets in 1 NEWS Colmar Brunton poll. https://www.tvnz.co.nz/one-news/new-zealand/pressure-mountsnational-falls-29-labour-skyrockets-in-1-news-colmar-brunton-poll

Peters, W. (2018a). Change versus a modified status quo: The New Zealand First perspective In S. Levine (Ed), Stardust and Substance: The New Zealand General Election of 2017 (pp. 41-44). Victoria University Press.

Peters, W. (2018b, May 3). Capitalism with a human face. Speech to students at Victoria University of Wellington. https://www.beehive.govt.nz/speech/capitalism-human-face

Prebble, R. (2017, October 20). Jacinda Ardern will regret this coalition of losers. New Zealand Herald. https://www.nzherald.co.nz/opinion/news/article.cfm?c_id=466\&objectid=11935125

The Press (2019, January 29). Is a blue-green party a real possibility? Stuff. https://www.stuff.co.nz/the-press/opinion/110205536/is-a-bluegreen-party-a-real-possibility

Roy Morgan (2020, 1 June). PM Jacinda Ardern ascendant as Labour support (56.5\%) is now more than double National (26.5\%) three months from NZ Election. https://www.roymorgan.com/findings/8429-nz-national\%20-voting-intention-may-2020202006010651?fbclid=IwAR1XpbURHldJVB4m970ViP7xhaCVfzYI1K21YttZT0_uNU2b3 TLSOpUANBk

Rutherford, H. (2019, October 17). Fair Pay Agreements 'kicked for touch' with fresh round of consultation. New Zealand Herald. https://www.nzherald.co.nz/business/news/article.cfm?c_id=3\&objectid=12277311

Sachdeva, S. (2019, March 1). Future of work inquiry terms released. Newsroom. https://www.newsroom.co.nz/2019/03/01/466054/future-of-work-inquiry-terms-released 
Sadler, R., \& Stanford, E. (2020, June 28). ACT Party candidate Nicole McKee wants 'commonsense and practicalities' brought back into Government. Newshub. https://www.newshub.co.nz/home/politics/2020/06/act-party-candidate-nicole-mckee-wantscommonsense-and-practicalities-brought-back-into-government.html

Shaw, J. (2018), The Green Party's campaign: A Leader's perspective. In S. Levine (Ed), Stardust and Substance: The New Zealand General Election of 2017 (pp. 45-54). Victoria University Press.

Skilling, P. (2019). Another swing of the pendulum: Rhetoric and argument around the Employment Relations Amendment Act (2018). New Zealand Journal of Employment Relations, 44(1), 5978.

Skilling, P. \& Molineaux, J. (2017). New Zealand's minor parties and ER policy after 2017. New Zealand Journal of Employment Relations, 42(2), 110-128.

Smellie, P. (2020, 12 July) 'Only two things can rescue Muller and the National Party now'. New Zealand Herald. https://www.nzherald.co.nz/business/news/article.cfm?c_id=3\&objectid=12347425

Soper, B. (2017, November 7). Winston peters takes legal action against nine people he believes helped leak pension overpayment info. New Zealand Herald. https://www.nzherald.co.nz/nz/news/article.cfm?c_id=1\&objectid=11941372

Tibshraeny, J. (2019, October 15). Peters tells unionists wanting a fair pay agreement framework legislated that change can't happen overnight. interest.co.nz. https://www.interest.co.nz/business/102138/winston-peters-tells-unionists-wanting-fair-payagreement-framework-legislated

Walls, J. (2020, July 26). Advance NZ - Jami-Lee Ross joins forces with controversial NZ Public Party. New Zealand Herald https://www.nzherald.co.nz/nz/news/article.cfm?c id=1\&objectid=12351040

Young, A. (2020a, August 4). Green Party confidence and supply deal - report card. New Zealand Herald.

https://www.nzherald.co.nz/premium/news/article.cfm?c_id=1504669\&objectid=12353215

Young, A. (2020b, September 23). Election 2020: Act's job is to destroy NZ First vote says National's Judith Collins. New Zealand Herald. https://www.nzherald.co.nz/nz/news/article.cfm?c_id=1\&objectid=12367428 